\title{
Management of Atrial Fibrillation Leading to BRASH Syndrome: Case Report
}

Ali Laalou*, Ikram Hazzazi, Nadia Charei, Mohammed El Jamili, Dounia Benzeroual, Saloua El Karimi, Mustapha El Hattaoui

Cardiology Department, Mohammed VI University Hospital, Marrakesh, Morocco

\begin{tabular}{ll}
\hline DOI: $10.36347 /$ sasjm.2021.v07i04.006 & | Received: 18.03 .2021 | Accepted: 24.04 .2021 | Published: 29.04 .2021 \\
*Corresponding author: Ali Laalou &
\end{tabular}

*Corresponding author: Ali Laalou

Abstract

BRASH Syndrome is an acronym for Bradycardia, Renal failure, Atrioventricular (AV) node blocker, Shock and Hyperkalemia. This is a rare clinical entity, few medical articles are found in the literature review. The diagnosis should be suggested in patients on a combination of anti-arrhythmic drugs. We report a case of BRASH syndrome complicating the management of atrial fibrillation with high ventricular rate.

Keywords: BRASH Syndrome, anti arrhythmics, shock.

Copyright $\left({ }_{0} 2021\right.$ The Author(s): This is an open-access article distributed under the terms of the Creative Commons Attribution 4.0 International License (CC BY-NC 4.0) which permits unrestricted use, distribution, and reproduction in any medium for non-commercial use provided the original author and source are credited.

\section{INTRODUCTION}

Brash syndrome is an acronym for Bradycadia, Renal failure, atrioventricular node blocker, shock and Hyperkaliemia.

In this article, we report a case of Brash syndrome complicating the managment of atrial fibrillation with high ventricular rate.

\section{CASE PRESENTATION}

A 62-year old man presented to the emergency department with one year history of palpitations, initially intermittent, then permanent 7 days prior to admission. He developed progressively worsening dyspnea (NYHA class II-III). He had no associated chest pain, lipothymia nor syncope.

On examination, his blood pressure was $100 / 50 \mathrm{mmHg}$, and he had a rapid irregular heart rate at 220 beats per minute. The electrocardiogram (EKG) reveled an atrial fibrillation with a rapid ventricular response (Figure 1):

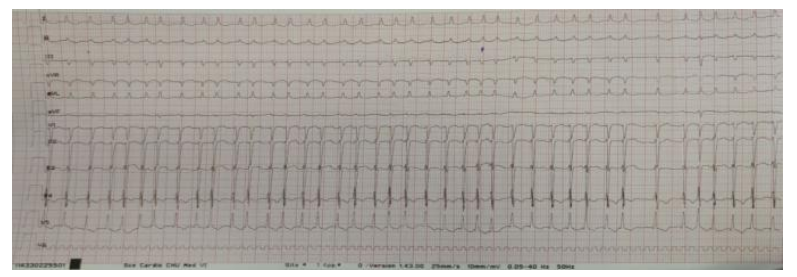

Fig-1: Initial EKG showing atrial fibrillation at high ventricular rate
Transthoracic echocardiogram showed a normal-sized left ventricle, a slightly dilated left atrium along with markedly dilated and hypertrophic right cavities. The ejection fraction (EF) per tachycardia was estimated at $40 \%-45 \%$. We were not able to estimate the pulmonary artery pressure (sPAP) given the patient's tachycardia.

Chest computerized tomography (CT) paired with computed tomography angiography (CTA) were performed and showed no signs of proximal pulmonary embolism. There was, however, moderate bilateral pleural effusion, ground-glass opacities with bullous paraseptal emphysema lesions in the upper lobes of the lungs and linear atelectasis in the middle lobe. Thyroid function tests revealed a hyperthyroidism with low TSH and elevated T4. Thyroid ultrasonography revealed diffuse thyroid enlargement with multiple low risk nodules in the right lobe rated EU-TIRADS 3.

The remaining of the biological workup showed normal renal and hepatic functions, no anemia, and a negative $\mathrm{C}$ - reactive protein test.

Carbimazole was initiated to treat the hyperthyroidisme, along with anticoagulation with enoxaparine. We have opted for rate control given the probability of chronic atrial fibrillation, and considering that hyperthyroidism is associated with a high rate of cardioversion failure.

Following the recommendations, the patient was put on oral bisoprolol and digoxin. On the third

Citation: Ali Laalou et al. Management of Atrial Fibrillation Leading to BRASH Syndrome: Case Report. SAS J Med, 2021 April 7(4): 148-151. 
day, we noted no improvement in symptoms, so we switched to propranolol which has shown its effectiveness in the context of hyperthyroidism. On the fifth day, the ventricular rate remained uncontrolled. We screened the patient for atrial thrombi by transesophageal echocardiography (TEE) before attempting an electrical cardioversion that failed to normalise the heart rate. On the seventh day, our patient developed dyspnea and wheezing. We therefore decided to switch the verapamil and propranolol with atenolol which is cardioselective and has demonstrated efficacy in the context of dysthyroidism.

Amiodarone was not initiated given the risk of thyrotoxicosis, we started diltiazem with EKG and biological monitoring and the patient remained on atenolol $100 \mathrm{mg}$, digoxin $0,25 \mathrm{mg}$ and diltiazem $60 \mathrm{mg}$ three times a day.

The rate control was obtained after 3 days of this association (Figure 2). The patient was then discharged symptom frees with a prescription of Atenolol $100 \mathrm{mg}$ and diltiazem $60 \mathrm{mg}$ three times a day. The biological workup showed normal renal function and a potassium level at $4.3 \mathrm{Meq} / \mathrm{l}$.

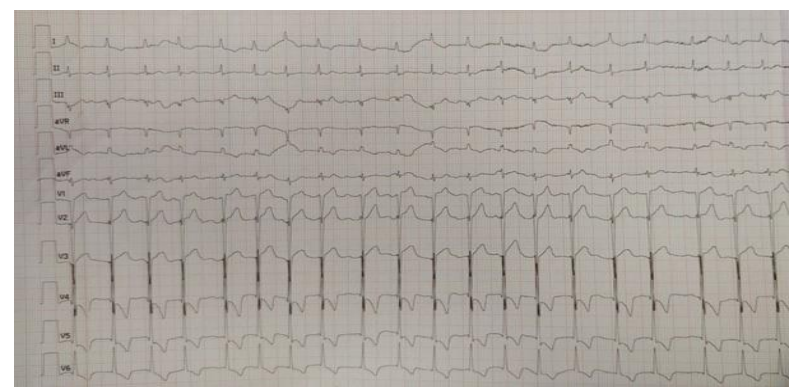

Fig-2: EKG after antiarrhythmic drugs

One week later, the patient presented with signs of shock: heavy sweating and severe hypotension. EKG showed high degree heart block. The patient underwent temporary cardiac pacing Figure 4-5.

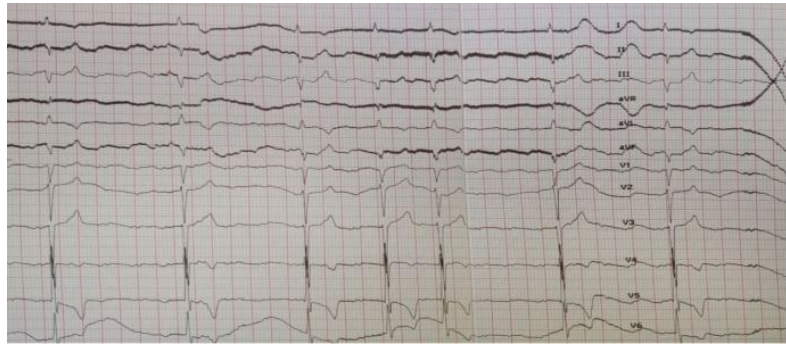

Fig-3: EKG showing a high degree heart block

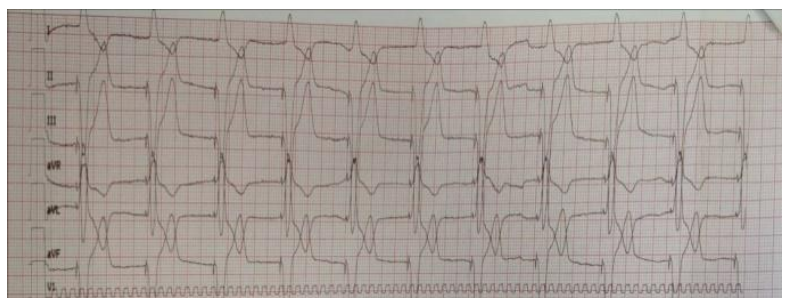

Fig-4: EKG after pacing

Laboratory investigations revealed a moderate hyperkalemia at $6,8 \mathrm{meq} / \mathrm{l}$, acute renal failure with anuria. Dialysis could not be carried out considering the hemodynamic instability. Unfortunately, the patient died a few hours later.

\section{DISCUSSION}

The rate control management in atrial fibrillation is essentially based on intravenous betablockers, calcium channel blockers and cardiac glycosides which must be available in every hospital [1]. Unfortunately, in Morocco those emergency drugs are unavailable, leading to the association of many antiarrhythmics with risk of interaction and increased side effects.

We suggest that our patient developed a BRASH syndrome after his discharge from the hospital, which is an acronym for Bradycardia, Renal failure, Atrioventricular (AV) node blocker, Shock and Hyperkalemia.

The pathophysiology leading to BRASH syndrome was described in different articles (Figure 5).

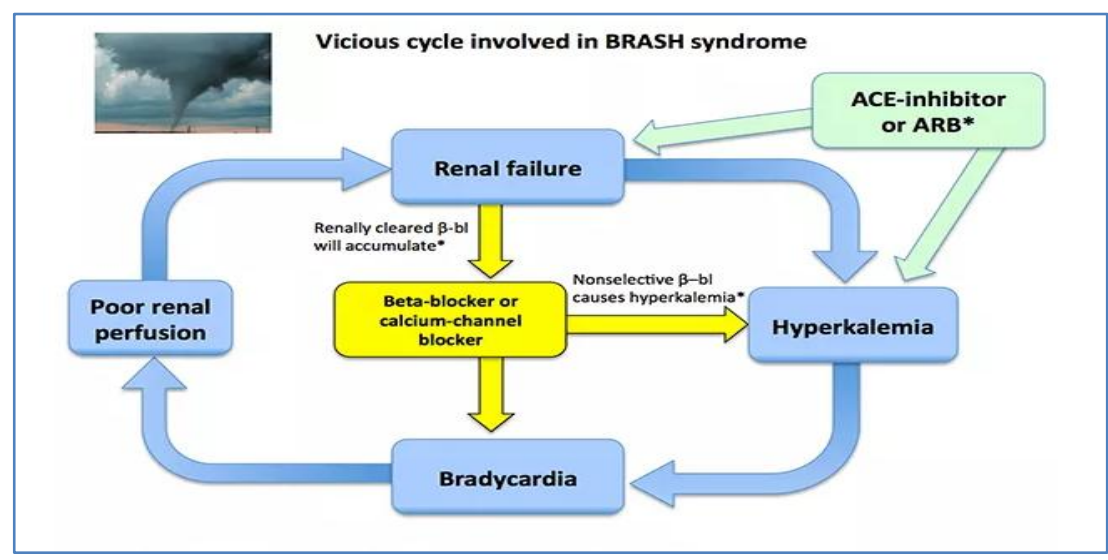

Fig-5: BRASH (Bradycardia, Renal failure, AV blockade, Shock, and Hyperkalemia) pathophysiology (7). ACE = angiotensin converting enzyme; ARB = angiotensin-receptor blocker [4-16] 
BRASH syndrome is a rare entity. The cases linked to the use of betablockers and borderline renal function are reported in the articles listed below (Table 1) $[5,6,7,8,9,10,11,12,13,14]$.

Table-1: Reported Cases of BRASH Syndrome [5, 6, 7, 8, 9, 10, 11, 12, 13, 14]

\begin{tabular}{|c|c|c|c|c|c|c|}
\hline $\begin{array}{l}\text { Age, } \\
\text { Bender }\end{array}$ & Medications involved & $\begin{array}{l}\text { Potassium } \\
\text { (mEg/l) }\end{array}$ & $\begin{array}{l}\text { Creatinine } \\
(\mathrm{m} / \mathrm{dL})\end{array}$ & Inlital vitals & Treatments & Reference \\
\hline $70 \mathrm{M}$ & $\begin{array}{l}\text { carvedilol } \\
\text { valsartan, spironolactone }\end{array}$ & 6.1 & 2.1 & $\begin{array}{l}\text { HR } 38, \text { Bp } \\
86 / 50\end{array}$ & $\begin{array}{l}\text { IV calcium } \\
\text { insulin / dextrose }\end{array}$ & Aziz 2011 \\
\hline $76 F$ & $\begin{array}{l}\text { carvedilol } \\
\text { spironolactone, ramipril }\end{array}$ & 9.2 & 1.3 & $\begin{array}{l}\text { HR 28, Bp } \\
120 / 59\end{array}$ & $\begin{array}{l}\text { Transvenous pacing } \\
\text { insulin/glucose, bicarbonate }\end{array}$ & Erden 2010 \\
\hline $78 \mathrm{~F}$ & $\begin{array}{l}\text { beta-blocker, ACE inhibitor } \\
\text { calcium-channel blocker }\end{array}$ & 7.9 & $\begin{array}{c}2.1 \\
\text { (prior 1.1) }\end{array}$ & HR 33 & $\begin{array}{l}\text { Calcium, insulin } \\
\text { furosemide, fluid }\end{array}$ & Unterman 2008 \\
\hline $70 \mathrm{M}$ & $\begin{array}{l}\text { metoprolol XL } 100 \mathrm{mg} \\
\text { enalapril, spironolactone }\end{array}$ & 6.5 & 3.3 & $\begin{array}{l}\text { HR 44, Bp } \\
100 / 56\end{array}$ & $\begin{array}{l}\text { Calcium, albuterol, kayexalate, } \\
\text { transvenous pacing, dialysis }\end{array}$ & Isabel 2006 \\
\hline $54 F$ & $\begin{array}{l}\text { atenolol } 100 \mathrm{mg} \text {, diltiazem } 300 \mathrm{mg} \\
\text { irbesartan }\end{array}$ & 6.4 & $160 \mathrm{uM}$ & $\begin{array}{l}\text { HR 22, Bp } \\
60 / 30\end{array}$ & $\begin{array}{l}\text { External pacer, fluid, calcium, } \\
\text { insulin }\end{array}$ & Bonvini 2006 \\
\hline $57 \mathrm{M}$ & $\begin{array}{l}\text { carvedilol } 50 \mathrm{mg} \text { bid, digoxin } \\
\text { spironolactone, fosinopril }\end{array}$ & 6.8 & 2.7 & $\begin{array}{l}\text { HR 48, Bp } \\
100 / 60\end{array}$ & & Vuckovic 2004 \\
\hline $78 \mathrm{M}$ & metoprolol, lisinopril & 7.5 & 8.5 & $\begin{array}{l}\text { HR } 30, \text { Bp } \\
120 / 60\end{array}$ & $\begin{array}{l}\text { Transvenous pacing, calcium, } \\
\text { furosemide, bicarbonate }\end{array}$ & Zimmers 2002 \\
\hline $66 \mathrm{~F}$ & verapamil SR $360 \mathrm{mg}$ & 7.1 & 6.1 & $\begin{array}{l}\text { HR 26, Bp } \\
85 / 60\end{array}$ & $\begin{array}{l}\text { Isoproteranol, dopamine, calcium } \\
\text { Bicarbonate, insulin, glucose }\end{array}$ & Vazquez 1996 \\
\hline $75 F$ & $\begin{array}{l}\text { verapamil } 120 \mathrm{mg} \text { TID } \\
\text { captopril }\end{array}$ & 6.9 & 2.4 & HR $30,8 p 70 /$ & $\begin{array}{l}\text { Atropine, isoproterenol, calcium } \\
\text { pacemaker }\end{array}$ & Jolly 1991 \\
\hline $53 \mathrm{M}$ & $\begin{array}{l}\text { verapamil } 120 \mathrm{mg} \text { QID } \\
\text { propranolol } 40 \mathrm{mg} \text { QID }\end{array}$ & 6.8 & 1.6 & HR 32, Bp 70/ & Isoproterenol, dopamine & Lee 1986 \\
\hline
\end{tabular}

This syndrome is frequently underdiagnosed, leading to delayed treatment. Treatment of BRASH syndrome includes the stabilisation of the hemodynamic status with fluid resuscitation and vasopressors, and hyperkalemia therapies.

The BRASH syndrome in our patient was probably due to the association of beta blockers and digoxin. Within the patients presenting atrioventricual node block (AV block), high risk patients for developing a BRASH syndrome are those of advanced age, with moderate renal failure and episodes of dehydration. Prognosis is good with early recognition and management of this rare clinical entity as reported in Golchin and al paper of an 84-year-old man with a medical history of hypertension who presented with weakness and polyuria. The patient was on betablockers; the examination showed hypotension and bradycardia. Laboratory values revealed acute renal failure and hyperkalemia of 7.1. The patient was given intravenous calcium, intravenous fluids, and insulin with dextrose and put on dopamine drip. The patient received emergent dialysis with a good evolution [15].

\section{CONCLUSION}

BRASH syndrome is a process resulting in a combination of hyperkalemia and medications blocking the AV node.

This syndrome should be suggested in polymedicated old patients as it are frequently underdiagnosed, leading to delayed treatment. Timely diagnosis and early managment of this rare clinical entity enables better outcomes.
We insist on the fact that the injectable treatments must be available in Morocco to avoid the side effects of drug combinations potentially leading to complications such as BRASH syndrome.

\section{REFERENCES}

1. 2020 Guidelines for Management of Atrial Fibrillation. ESC Clinical Practice Guidelines

2. Jastrzębska H. Effects of amiodarone on the thyroid function. Postępy Nauk Med. 2012; 11: 882-888. 6. Ngo SuY, Chew HC. When the storm passes unnoticed - a case series of thyroid storm. Resuscitation. 2007.

3. Yamashita $Y$, Iguchi $M$, Nakatani R, Usui $T$, Takagi D, Hamatani Y, Unoki T, Ishii M, Ogawa $\mathrm{H}$, Masunaga N, Abe M. Thyroid storm with heart failure treated with a short-acting betaadrenoreceptor blocker, landiolol hydrochloride. Internal Medicine. 2015;54(13):1633-7.

4. Farkas JD, Long B, Koyfman A, Menson K. BRASH syndrome: bradycardia, renal failure, av blockade, shock, and hyperkalemia. The Journal of emergency medicine. 2020 Aug 1;59(2):216-23.

5. Aziz EF, Javed F, Korniyenko A. Mild hyperkalemia and low eGFR a tedious recipe for cardiac disaster in the elderly: an unusual reversible cause of syncope and heart block. Heart Int; 2011.

6. Erden I, Yalcin S, Ozhan H. Syncope caused by hyperkalemia during use of a combined therapy with the angiotensin-converting enzyme inhibitor and spironolactone. Kardiol Pol; 2010.

7. Unterman A, Moscavitch SD. The silence of the atria. Isr Med Assoc J; 2008.

8. Isabel J, Champion JC. Junctional escape rhythm secondary to acute hyperkalemic renal failure in the 
setting of concurrent beta-blocker therapy. JAAPA; 2006

9. Bonvini RF, Hendiri T, Anwar A. Sinus arrest and moderate hyperkalemia. Ann Cardiol Angeiol (Paris); 2006

10. Vuckovic K, Richlin D. Bradycardia induced by hyperkalemia. AAOHN J; 2004.

11. Zimmers T, Patel H. Cases in electrocardiography. Am J Emerg Med; 2002?

12. Vazquez C, Huelmos A, Alegriza E, Errasti P, Purroy A. Verapamil deleterious effects in chronic renal failure. Nephron; 1996.
13. Jolly SR, Keaton N, Movahed A. Effect of hyperkalemia on experimental myocardial depression by verapamil. Am Heart J; 1991.

14. TH, Salomon DR, Rayment CM, Antman EM. Hypotension and sinus arrest with exercise-induced hyperkalemia and combined verapamil/propranolol therapy. Am J Med; 1986.

15. Golchin K, Zhou M, Khan AH. Bradycardia, renal failure, AV-nodal blockers, shock, and hyperkalemia (BRASH) - a new clinical syndrome. Am J Respir Crit Care Med. 2018;197

16. Farkas J. BRASH syndrome: Bradycardia, Renal failure, Av blocker, Shock, and Hyperkalemia. Pulmcrit (EMCrit). 2016. 